\title{
Proliferation and Differentiation of Mouse Spermatogonial Stem Cells on a Three-Dimensional Surface Composed of PCL/Gel Nanofibers
}

\author{
Proliferación y Diferenciación de Células Madre Espermatogónicas de Ratón \\ en una Superficie Tridimensional Compuesta de Nanofibras PCL/Gel
}

\begin{abstract}
Ali Talebi ${ }^{1}$; Mohammad Ali Sadighi Gilani ${ }^{2}$; Morteza Koruji ${ }^{3}$; Jafar Ai ${ }^{4}$; Shadan Navid ${ }^{1}$; Mohammad Jafar Rezaie ${ }^{5}$; Ayob Jabari'; Sepideh Ashouri Movassaghi ${ }^{1}$ Farnaz Khadivi $^{1}$; Majid Salehi ${ }^{6}$; Yumi Hoshino ${ }^{7}$ \& Mehdi Abbasi ${ }^{1}$
\end{abstract}

TALEBI, A.; SADIGHI GILANI, M. A.; KORUJI, M.; AI, J.; NAVID, S.; REZAIE, M. J.; JABARI, A.; ASHOURI MOVASSAGH, S.; KHADIVI, F.; SALEHI, M.; HOSHINO, Y. \& ABBASI, M. Proliferation and differentiation of mouse spermatogonial stem cells on a three-dimensional surface composed of PCL/Gel nanofibers. Int. J. Morphol., 37(3):1132-1141, 2019.

SUMMARY: Spermatogonial stem cells (SSCs) have self-renewal and differentiation capacity essential for sperm production throughout the male reproductive life. The electrospun polycaprolactone/gelatin (PCL/Gel) nanofibrous scaffold mimics important features of the extracellular matrix (ECM), which can provide a promising technique for the proliferation and differentiation of SSCs in vitro. The goal of the present study was to investigate the effects of PCL/Gel nanofibrous scaffold on the propagation and differentiation of neonate mouse SSCs (mSSCs). mSSCs were enzymatically isolated, and the cells were purified by differential plating method and seeded on scaffold. After 2 weeks, viability, colony number and diameter, and expression of specific spermatogonial cell genes were investigated. After mSSCs propagation, the cells were cultivated in a differentiation medium on the scaffold for another 2 weeks, and differentiating cells were analyzed by real-time PCR. The number of mSSC colony $(\mathrm{P}<0.01)$ and expression levels of specific spermatogonial genes Plzf and Inga6 $(\mathrm{P}<0.01)$ and also differentiation genes c-Kit, Tp1 and Ptm1 $(\mathrm{P}<0.05)$ were higher in scaffold group compared with control during the culture period. We conclude that mSSCs can be expanded and can differentiate toward spermatid cells on PCL/Gel nanofibrous scaffold with improved developmental parameters.

KEY WORDS: Adult germline stem cell; Male infertility; Cell differentiation; Polycaprolactone; Nanofibers.

\section{INTRODUCTION}

Spermatogonial stem cells (SSCs), a subpopulation of adult stem cells, are located at the basement membrane in the epithelium of testis seminiferous tubules (Griswold, 2016). This stem cell reserve ensures gamete production throughout the male reproductive life, and preserves male fertility. Despite species differences, the process of spermatogenesis is similar between rodents and humans, hence, rodents are a common animal models for the study of spermatogenesis (Jan et al., 2012; Boitani et al., 2016; Yoshida, 2016). During the process of spermatogenesis in mouse, daughter cells of SSC (ASingle) divisions either stay in the stem cell population or enter the progenitor population for further differentiation of spermatogonia. Differentiating type-A spermatogonia undergo mitotic divisions leading to the generation of type-B spermatogonia which enter meiotic divisions and produce haploid male gametes (Griswold, 2016; Ibtisham et al., 2017). Testicular somatic cells such as Sertoli, myoid and leydig cells extrinsically regulate the process of spermatogenesis together with intrinsic regulators such as transcription factors produced by the spermatogonial cells (Mei et al., 2015). Sertoli cells form a major component of SSCs niche, and they play critical roles in the behavior of these cells. Although Sertoli cells stimulate self-renewal of SSC, they also promote SSCs differentiation via the

\footnotetext{
${ }^{1}$ Department of Anatomy, School of Medicine, Tehran University of Medical Sciences, Tehran, Iran.

${ }^{2}$ Department of Urology, Shariati Hospital, Tehran University of Medical Sciences, Tehran, Iran.

${ }^{3}$ Cellular and Molecular Research Center \& Department of Anatomical Sciences, Iran University of Medical Sciences, Tehran, Iran.

${ }^{4}$ Department of Tissue Engineering, School of Advanced Technologies in Medicine, Tehran University of Medical Sciences, Tehran, Iran.

${ }^{5}$ Department of Embryology, Faculty of Medicine, Kurdistan University of Medical Sciences, Sanandaj, Iran.

${ }^{6}$ Department of Tissue Engineering, School of Medicine, Shahroud University of Medical Sciences, Shahroud, Iran.

${ }^{7}$ Graduate School of Biosphere Science, Hiroshima University, Hiroshima, Japan.
} 
TALEBI, A.; SADIGHI GILANI, M. A.; KORUJI, M.; AI, J.; NAVID, S.; REZAIE, M. J.; JABARI, A.; ASHOURI MOVASSAGH, S.; KHADIVI, F.; SALEHI, M.; HOSHINO, Y. \& ABBASI, M. Proliferation and differentiation of mouse spermatogonial stem cells on a three-dimensional surface composed of PCL/Gel nanofibers. Int. J. Morphol., 37(3):1132-1141, 2019.

production of factors such as stem cell factor, retinoic acid and bone morphogenetic protein-4 (Hai et al., 2014). SSCs proliferation and commitment to differentiation is a complex and tightly regulated process that occur in the basal compartment of seminiferous tubules.

Chemotherapy and radiotherapy which are commonly used for the treatment of cancer and some non-malignant conditions such as drepanocytosis are gonadotoxic and can lead to germ cell loss and subsequently, infertility in patients (Dohle, 2010). Sperm banking is the main strategy for fertility preservation in adult men who are undergoing chemo and radiotherapy, however, this approach has not been used in prepubertal boys (Picton et al., 2015; Onofre et al., 2016). Testicular tissue grafting and cryopreservation of SSCs are the current practices for fertility preservation in prepubertal boys (Picton et al.; Onofre et al.). Animal model studies have demonstrated that fertility restoration can be achieved by the auto-transplantation of cryopreserved SSCs, or auto or xeno-grafting of testicular tissue and/or propagation and differentiation of SSCs in vitro (Goossens et al., 2013; Onofre et al.). Due to the rare number of SSCs in testis, coupled with the small size of testicular biopsies, in vitro enrichment of SSCs is an essential step in fertility restoration management (Goossens et al.).

Conventional two-dimensional (2D) culture systems and organ culture of testicular tissue increased our knowledge about in vitro spermatogenesis. Recently, much attention has been paid to three-dimensional (3D) culture systems which provide more spatial conditions that mimic the architecture of seminiferous tubules (Shams et al., 2017). Due to presence of SSCs on the basement membrane in a 3D microenvironment, the extracellular matrix may play an important role in the behavior of these cells. Hence, various 3D culture systems such as soft agar culture system (SACS), methylcellulose culture system (MCS), collagen gel matrix and alginate capsule have been developed for in vitro proliferation and differentiation of SSCs (Lee et al., 2006; Huleihel et al., 2015; Jalayeri et al., 2017; Navid et al., 2017).

In tissue engineering, key elements such as scaffolds are developed from various materials such as polymers and ceramics (O'Brien, 2011). Nanofiber scaffolds are artificial extracellular matrices which provide a 3D topography for cell interactions, and can be fabricated from both synthetic and natural polymers by different techniques (Ma et al., 2005). Co-polymerization and blending of synthetic and natural polymers allow modification of their biophysical properties and exploitation of the advantages of both types of polymers (Sabir et al., 2009). Polycaprolactone (PCL) is a biodegradable and biocompatible synthetic polymer with semi-crystalline structure and low glass-transition temperature. This synthetic polymer is extensively used for tissue engineering applications in different formulations such as scaffold, films, hydrogel, composite and etc. Gelatin (Gel) is a natural polymer derived from collagen, and due to its properties, it has been widely used in tissue engineering (Dash \& Konkimalla, 2012). Until now, various synthetic and natural biomaterials have been employed to support the adhesion and proliferation as well as the acceleration of the differentiation of different kinds of stem cells. In this regard, the behavior of SSCs has been evaluated in culture systems utilizing 3D surfaces such as poly L-lactic acid (PLLA) and polyamide(Ultra-Web ${ }^{\mathrm{TM}}$ ) nanofibers (Eslahi et al., 2013; Shakeri et al., 2013). However, differentiation of SSCs on 3D nanofibrous surfaces has not been investigated.

In fertility preservation approaches and in vitro spermatogenesis studies, development of an appropriate in vitro culture system for SSCs expansion and differentiation with high efficiency is an important goal. In the present study, we aim to investigate the proliferation and differentiation of neonate mouse SSCs (mSSCs) on electrospun nanofibrous PCL/Gel scaffold.

\section{MATERIAL AND METHOD}

Reagents. All chemicals were purchased from SigmaAldrich (St. Louis, USA) unless otherwise stated. Primary antibodies and secondary antibodies were supplied by Abcam Inc. (Cambridge, MA, USA).

Animals. Testicular cells were obtained from 3 to 6-day old National Medical Research Institute (NMRI) male mice. Animals were bred and kept with free access to food and water under controlled conditions (12-h light/12-h dark cycle, and $22-25^{\circ} \mathrm{C}$ temperature). All animal care and experimental procedures were approved by the Ethics Committee of Tehran University of Medical Sciences (IR.TUMS.MEDICINE.REC.1396.2507).

Electrospinning of PCL/Gel Nanofibrous Scaffold. PCL $(\mathrm{Mw}=48-90 \mathrm{kDa})$ and $\mathrm{Gel}$ (Type B, bovine skin) solutions were prepared at the same concentration of $14 \%(\mathrm{w} / \mathrm{v})$ at room temperature in the presence of acetic acid as a cosolvent. PCL and Gel solutions were mixed at a ratio of 1:1. The reaction mixture was stirred for $24 \mathrm{~h}$ and then loaded into a $10 \mathrm{~mL}$ disposable syringe (18-gauge needle). The polymer solution was fed to a syringe pump (Fanavaran Nano-Meghyas, Tehran, Iran) connected to a collector at a feed rate of $0.4 \mathrm{~mL} / \mathrm{h}$. Distance between collector and tip of syringe needle was set at $15 \mathrm{~cm}$. The metal collector was covered with an aluminum foil sheet. By a high voltage 
TALEBI, A.; SADIGHI GILANI, M. A.; KORUJI, M.; AI, J.; NAVID, S.; REZAIE, M. J.; JABARI, A.; ASHOURI MOVASSAGH, S.; KHADIVI, F.; SALEHI, M.; HOSHINO, Y. \& ABBASI, M. Proliferation and differentiation of mouse spermatogonial stem cells on a three-dimensional surface composed of PCL/Gel nanofibers. Int. J. Morphol., 37(3):1132-1141, 2019.

supply (Fanavaran Nano-Meghyas, Tehran, Iran), the voltage between the collector and needle was maintained at $20 \mathrm{kV}$.

Characterization of Nanofibrous Scaffold. The morphology of scaffolds was examined with scanning electron microscope (SEM, CamScan, MV2300, UK) at an accelerating voltage of $26 \mathrm{kV}$. Before SEM viewing, dried scaffolds were coated with gold using sputter coater (Quorum technologies, UK). Fiber diameter was calculated from SEM images by using the image analysis software ImageJ (National Institutes of Health, USA). Total porosity was determined by liquid displacement method using ethanol (Salehi et al., 2018). The scaffold was immersed in a cylinder containing a known volume (V1) of ethanol. Pressurization and depressurization cycle was conducted using the cylinder which was placed in a vacuum to force the liquid into the pores of the scaffold. The total volume of the ethanol-soaked scaffold was then calculated as V2. The ethanol-soaked scaffold was removed and the residual liquid volume was recorded as V3. The porosity of the scaffolds was calculated using the following equation (). The tensile properties of the scaffold were determined by uniaxial tensile testing device (Santam, Karaj, Iran) at 1 mm/ min extension rate. The wettability of electrospun scaffolds was determined by Sessile drop method using a contact angle measuring system (KRUS, Hamburg, Germany) (Farzamfar et al., 2017).

Spermatogonial Cell Isolation. For testicular cells isolation, testes were collected from 3 to 6-day old neonate mice, and were transferred into phosphate buffer saline (PBS; Gibco, USA) solution. Two-step enzymatic digestion method was used for tissue digestion. Tunica albuginea was removed from all testes before enzymatic digestion. Minced testis pieces were suspended in a digestion solution containing collagenase type IV (Gibco, $1 \mathrm{mg} / \mathrm{mL}$ ), DNase $(10 \mathrm{mg} / \mathrm{mL})$, and hyaluronidase $(0.5 \mathrm{mg} / \mathrm{mL})$ for $20 \mathrm{~min}$ at $37^{\circ} \mathrm{C}$ in a $5 \% \mathrm{CO}$ incubator. After centrifugation at 1,500 $\mathrm{g}$ for $5 \mathrm{~min}$, the cell pellet was re-suspended in fresh a digestion solution and incubated for $15 \mathrm{~min}$ in an incubator. Pipetting was performed every $5 \mathrm{~min}$ at each digestion step to ensure efficient digestion. Cell suspension was then centrifuged at 1,500 $\mathrm{g}$ for $5 \mathrm{~min}$ and the cell pellet was washed in PBS. mSSC purification was carried out using differential plating method and the same modifications described in our previous study (Navid etal.).

SSC Culture for Propagation and Differentiation. For cell propagation, mSSCs were cultivated in Minimum Essential Medium Eagle solution (alpha-MEM) medium supplemented with $10 \%$ fetal bovine serum (FBS), 1x nonessential amino acids (Invitrogen, USA), 0.1 mM 2mercaptoethanol, $103 \mathrm{U} / \mathrm{mL}$ human recombinant leukemia inhibitory factor (LIF), $10 \mathrm{ng} / \mathrm{mL}$ glial cell line-derived neurotrophic factor (GDNF), $100 \mathrm{U} / \mathrm{mL}$ penicillin and 100 $\mathrm{mg} / \mathrm{mL}$ streptomycin for 2 weeks. The culture medium was replaced every 3 days and the cells were sub-cultured every 7 days during cultivation period. The cell culture plates were incubated at $37^{\circ} \mathrm{C}$ in an atmosphere humidified with $5 \% \mathrm{CO}_{2}$. After enrichment, the cells were cultivated for another 2 weeks in a differentiation medium which had the same composition as the proliferative medium but without GDNF and LIF.

Cell Viability. Viability of testicular cells was evaluated by using Methylthiazolyldiphenyl-tetrazolium bromide (MTT) assay at days 3, 7 and 14. The cells were incubated in alpha-MEM medium containing $0.5 \mathrm{mg} / \mathrm{mL}$ MTT for 4 h. Following incubation, cells lysed and purple formazan crystals were dissolved by adding dimethyl sulfoxide (DMSO). The final concentration of the cells was $1.5 \times 104$ cells per well of a 96-well plate. Subsequently, the plate was kept in an incubator for $30 \mathrm{~min}$ at room temperature. The optical density (OD) of each well solution was measured at $570 \mathrm{~nm}$ wavelength with a microplate reader (EONTM, BioTek, USA).

Colony Formation Assay. mSSCs proliferated and formed colonies during proliferative cultivation. We measured the number and diameter of colonies in each group at the 7 th and $14^{\text {th }}$ day of culture. Colony diameter was determined using ocular grid on inverted microscope (CKX41, Olympus, Japan) in the control group and by SEM in the scaffold group. Captured images were analyzed by ImageJ software.

Immunofluorescence Staining. For the characterization of mSSCs colonies, immunocytochemistry technique was used to detect the expression of promyelocytic leukemia zinc finger protein (PLZF) and thymus cell antigen-1 (THY1). Following fixation with $4 \%$ paraformaldehyde (Merck KGaA, Darmstadt, Germany) and permeabilization by $0.4 \%$ Triton X100, nonspecific antibody reaction was blocked with $10 \%$ goat serum. The cells were then incubated at a 1:100 dilutions with PLZF and THY1 antibodies (undifferentiated spermatogonia markers) for $2 \mathrm{~h}$ at $37^{\circ} \mathrm{C}$. After being washed three times with PBS, donkey anti-rabbit antibody (1:100) labeled with fluorescent isothiocyanate (FITC) was added for $3 \mathrm{~h}$ at room temperature. Nuclei were counterstained with 4,6diamidino-2-phenylindole (DAPI, $1 \mathrm{mg} / \mathrm{mL}$ ).

Real-Time qRT-PCR. After the proliferative period during culture ( 2 weeks), the cells were evaluated for the expression of the spermatogonial markers inhibitor of DNA binding protein-4 (Id4), Plzf, integrin alpha-6 (Inga6) 
TALEBI, A.; SADIGHI GILANI, M. A.; KORUJI, M.; AI, J.; NAVID, S.; REZAIE, M. J.; JABARI, A.; ASHOURI MOVASSAGH, S.; KHADIVI, F.; SALEHI, M.; HOSHINO, Y. \& ABBASI, M. Proliferation and differentiation of mouse spermatogonial stem cells on a three-dimensional surface composed of PCL/Gel nanofibers. Int. J. Morphol., 37(3):1132-1141, 2019.

and GDNF family receptor alpha-1 (Gfra1) genes by realtime PCR. Subsequently, the cells were also evaluated for the expression of the differentiation markers tyrosineprotein kinase Kit (c-Kit), Scp3, transition protein-1 (Tp1) and protamine-1 (Ptm1) after the differentiation period (2 weeks). The primer sequences of the genes are shown in Table I. Total RNA was extracted by Trizol reagent (Ready Mini Kit, Qiagen, USA), according to the manufacturer's protocol. Real-time PCR was performed by cDNA synthesis kit (Transcript First Strand cDNA Synt, Roche, USA) using $1 \mathrm{mg}$ of total RNA, according to the manufacturer's protocol. Real-time PCR was performed using forty-reaction amplification cycles, and Applied Bioscience 7500 fast with SYBR Green detection was used for the analysis. To check for the presence of non-specific PCR products, melting curve analysis was done. All samples were normalized against b-actin gene expression (internal control).

Table I. The sequence of primers used in real-time PCR.

\begin{tabular}{cc}
\hline Gene name & \multicolumn{1}{c}{ Primers (5' to 3') } \\
\hline Id ${ }^{*}$ & F: ACTCACCCTGCTTTGCTG \\
R: ATGCTGTCACCCTGCTTG & F: CGTTGGGGGTCAGCTAGAAAG \\
Rlzf & F: CACCATGATGACCACATCGC \\
& R: CTTCAGGCAATCTTCCAGG \\
Gfral & F: AGCCTTCTACCTGGACAC \\
& R: CCTGTTCTGTTTGCCCTC \\
Itga6 & F: CCTCAAACAAGTCACCTCC \\
& R: GCTTTACCTGGGCTATGTG \\
F-Kit & F:CCGCTGAGCAAACATCTAAAGATG \\
& R: GGAGCCTTTCATCAGCAACAT \\
Scp3 & F: TGTGATGCGGCAATGAGC \\
& R: CGACTGGGATTTACCCACTC \\
Tp1 & F: GAAGACTGTAAGGCTAAGAAAG \\
& R: AGGATGACTGAAAAGAGGAAG
\end{tabular}

Statistical Analysis. Data from replicated experiments are expressed as mean \pm standard deviation (SD). The statistical differences between and within groups were assessed by independent $t$ test and one-way analysis of variance (ANOVA) followed by Turkey post hoc test. Differences were considered significant at $P$ value of less than 0.05 .

\section{RESULTS}

Scaffold Characterization. SEM images of scaffolds revealed fibrils oriented in a random and dispersive manner, forming a non-woven porous structure. The morphology, diameter of fibers, porosity, tensile strength and wettability of scaffold are shown in Figure 1.

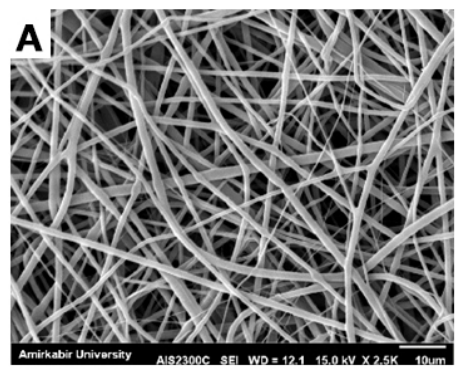

\begin{tabular}{cc}
\hline B & Mean \pm SD \\
\hline $\begin{array}{c}\text { Fiber } \\
\text { diameter } \\
\text { (nm) }\end{array}$ & $723 \pm 61$ \\
$\begin{array}{c}\text { Porosity } \\
\text { (\%) } \\
\text { Tensile } \\
\text { strength } \\
\text { (MPa) }\end{array}$ & $72.5 \pm 2.4$ \\
$\begin{array}{c}\text { Contact } \\
\text { angel ( }\end{array}$ & $78.18 \pm 0.62$ \\
\hline
\end{tabular}

Fig. 1. Scaffold characterization. SEM image of PCL/Gel scaffold (a). Fiber diameter, porosity and contact angle measurement of fabricated scaffold (b).

Cell Viability. Viability of the cells seeded on PCL/Gel scaffold was evaluated by MTT assay. The results show a higher viability of cells grown on scaffold compared with the control group, but the difference was only significant at day 7 of the culture period $(\mathrm{P}<0.01)$. As shown in Figure 2, on day 3 , OD in the scaffold group was $0.604 \pm 0.03$ vs $0.587 \pm 0.02$ in the control, and $0.971 \pm 0.1$ vs $0.874 \pm 0.03$ and $0.964 \pm 0.08$ vs $0.894 \pm 0.02(\mathrm{P}<0.05)$ on day 7 and 14 , respectively.

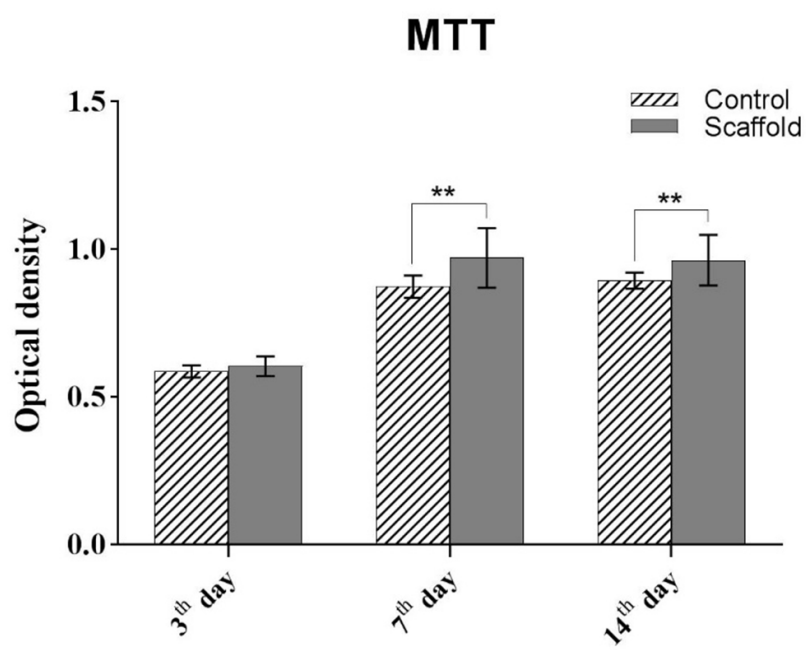

Fig. 2. MTT assay for cell viability. Optical density of the cells growing on PCL/Gel scaffold and in conventional culture system after 3, 7 and 14 days of cell seeding. Result are presented as mean $\pm \mathrm{SD}(* * \mathrm{P}<0.01)$. 

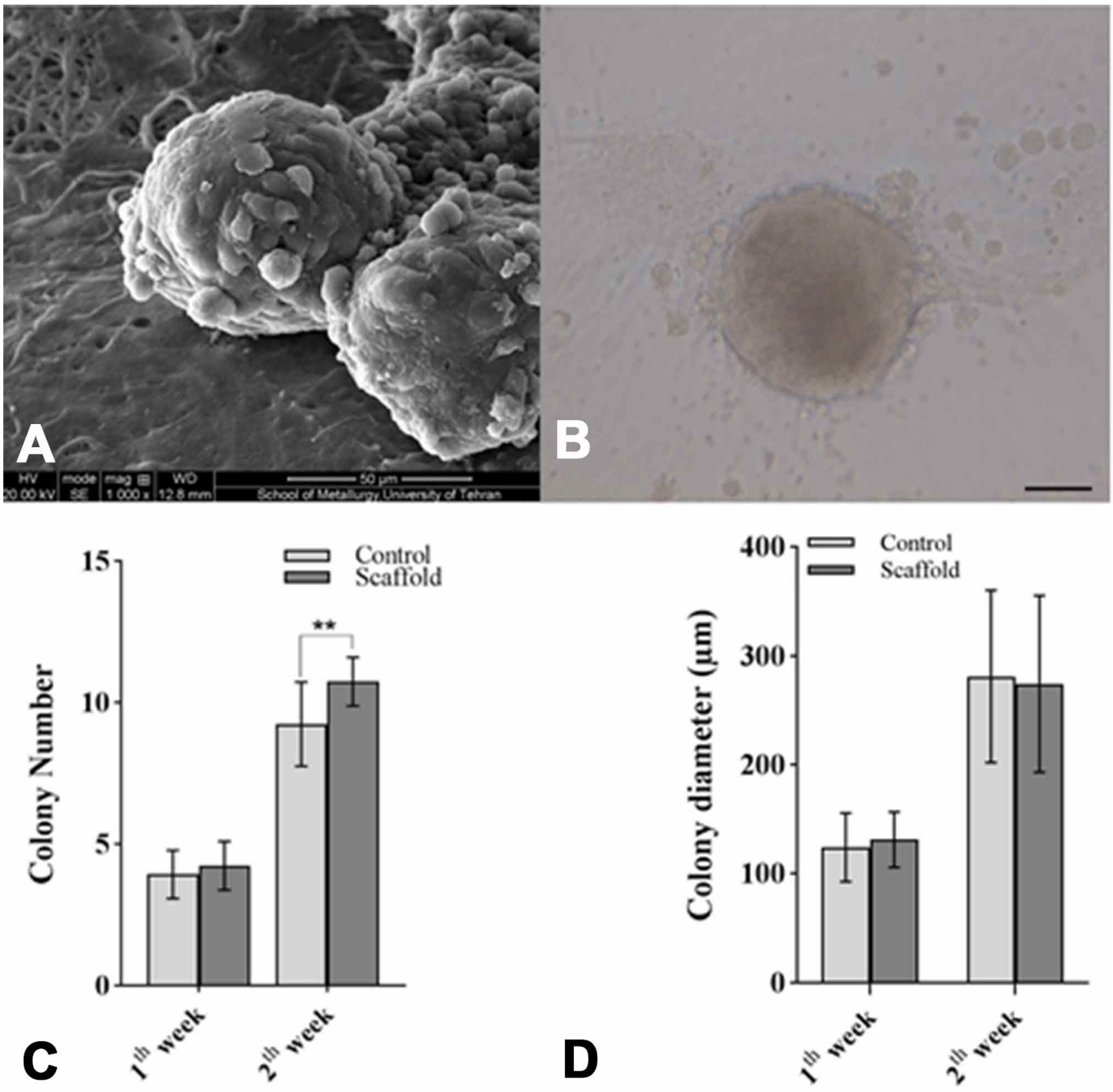

Fig. 3. Colony assay. The morphology (SEM image) of a mSSC colony growing on PCL/Gel scaffold (a), A colony growing in 2D conventional culture system (b), Colony number (c) and colony diameters -(d) in both groups at the end of 1th and 2th week of culture. All data are expressed as mean $\pm \mathrm{SD}(* * \mathrm{P}<0.01$, Scale bar $=50 \mu \mathrm{m})$.

Colony Assay. The number and diameter of colonies were calculated in both the scaffold and control groups (Fig. 3C,D). At the end of the first week, the difference between the mean number of colonies per well in the scaffold group ( $4.25 \pm 0.8)$ and the control group (3.94 \pm 0.8 ) was not significant, but at the end of second week, we observed a significant difference $(10.75 \pm 0.9$ in scaffold vs $9.25 \pm 1.5$ in control group, $\mathrm{P}<0.01)$. At 7 th day of culture, the average diameter of colonies formed on scaffold was $131 \pm 25$ vs $124 \pm 31$ in the control group, and the average was $274 \pm 81$ in the scaffold group vs $281 \pm 79$ in the control group $(\mathrm{P}<0.05)$ at 14 th day.

Immunostaining Evaluation of Colonies. After 2 weeks of culture, the colonies formed in both groups were positive for PLZF and THY1 which are markers of undifferentiated type-A spermatogonia (Fig. 4). 

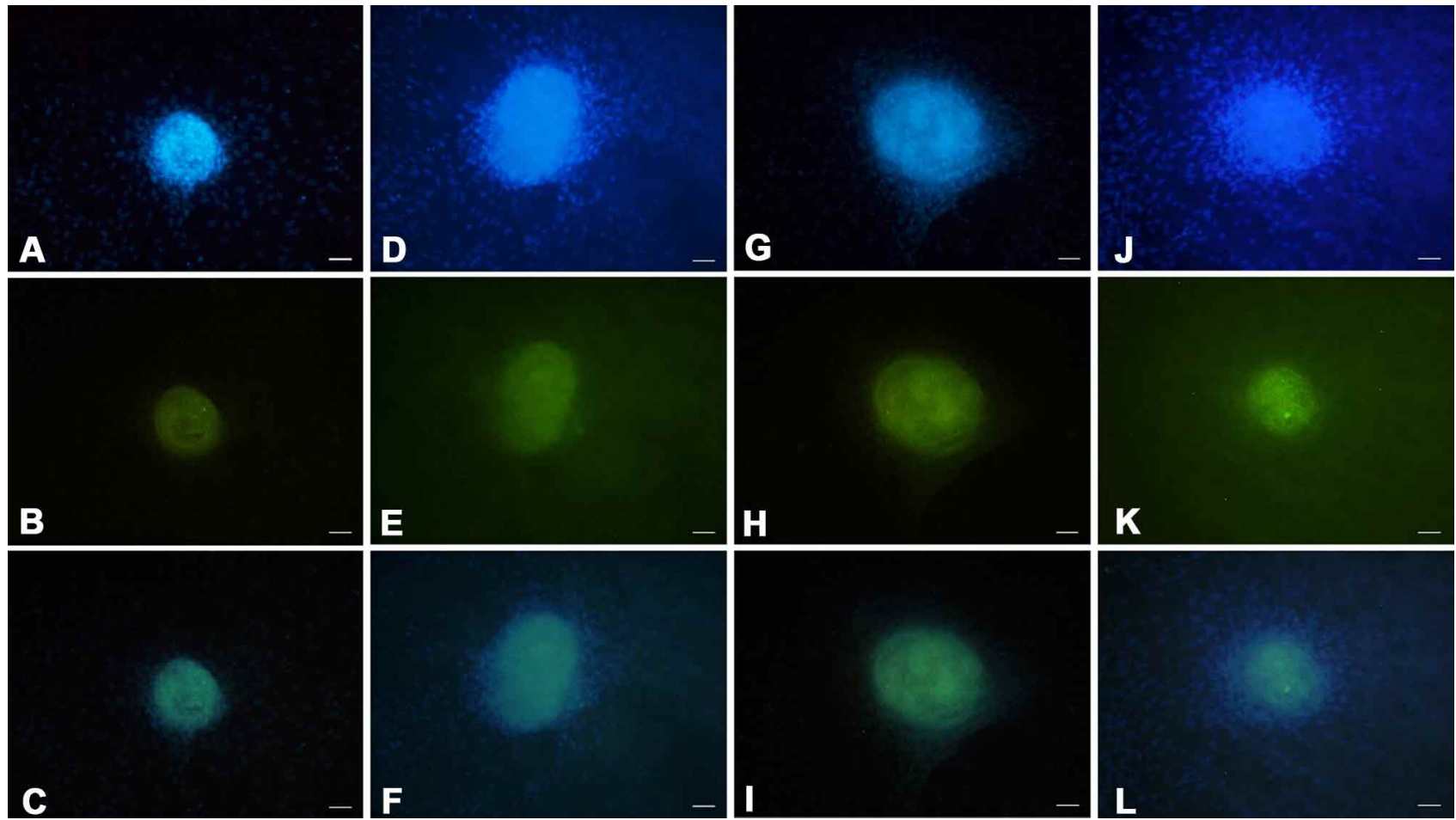

Fig. 4. Characterization of mSSC colonies by immunostaining. PLZF and THY1 were detected in colonies as spermatogonial cell markers ( $b$ and $h$ in control, e and $k$ on scaffold). DAPI staining ( $a, d, g$ and $j$ ) and merge of FITC and DAPI (c, f, i and l) are also shown $($ Scale bar $=50 \mu \mathrm{m})$.

Gene Expression During Proliferation and Differentiation Periods of Culture. At the end of the proliferative period of culture, we observed a higher level of expression of Id4, Plzf, Inga6, Gfra1 and c-Kit genes in the scaffold group compared with the control, but the differences were only significant for Plzf, Inga6 $(\mathrm{P}<0.01)$ and $\mathrm{c}-\mathrm{Kit}(\mathrm{P}<0.05)$ gene expression (Fig. 5A). After the differentiation period of culture ( 2 weeks), the levels of expression of Scp-3, Tp1 and Ptm1 were higher in the scaffold group than in the control, but significant differences were only observed in $\mathrm{Tp} 1$ and $\mathrm{Ptm} 1(\mathrm{P}<0.05)$ expression (Fig. 5B).
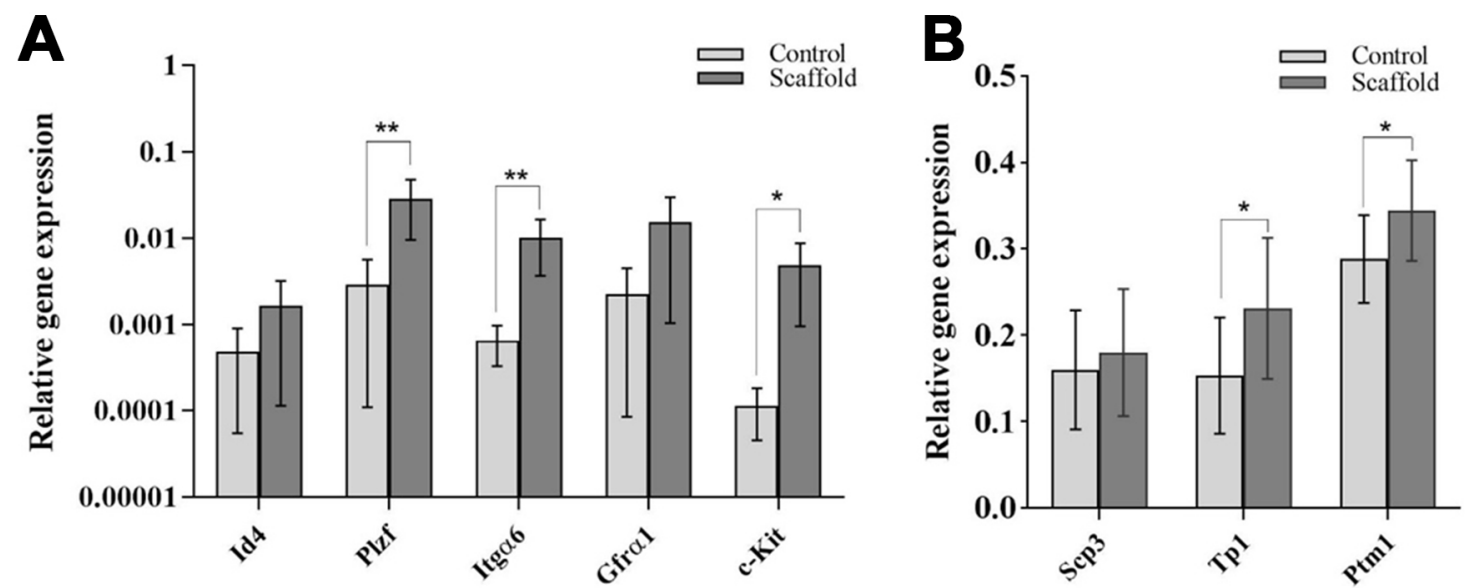

Fig. 5. Expression pattern of Id4, Plzf, Inga6, Gfra1 genes as undifferentiated type-A mouse spermatogonial cell markers and cKit gene as differentiating type-A mouse spermatogonial cell marker after 2 weeks of culture (a). Expression pattern of Scp3 (as meiotic marker), Tp1 and Ptm1 (as post-meiotic markers) genes in spermatogonial cells after 4 weeks of culture (b). The values are presented as mean \pm SD of gene expression relative to b-actin in both groups $(* \mathrm{P}<0.05, * * \mathrm{P}<0.01)$. Id4, inhibitor of DNA binding protein-4; Plzf, promyelocytic leukaemia zinc finger; Gfra1, GDNF family receptor alpha-1; Inga6, integrin alpha-6; cKit, tyrosine-protein kinase Kit; Scp3, synaptonemal complex protein-3; Tp1, transition protein-1; Ptm1, protamine-1. 
TALEBI, A.; SADIGHI GILANI, M. A.; KORUJI, M.; AI, J.; NAVID, S.; REZAIE, M. J.; JABARI, A.; ASHOURI MOVASSAGH, S.; KHADIVI, F.; SALEHI, M.; HOSHINO, Y. \&

ABBASI, M. Proliferation and differentiation of mouse spermatogonial stem cells on a three-dimensional surface composed of PCL/Gel nanofibers. Int. J. Morphol., 37(3):1132-1141, 2019.

\section{DISCUSSION}

In this study, we demonstrated that mSSCs can survive, proliferate and differentiate toward round spermatid on PCL/ Gel nanofiber scaffold. On this 3D surface, colonization and differentiation of mSSCs were improved compared with conventional culture system (2D culture system in cell culture plates). In our study, electrospun nanofiber scaffold mimicked nanotopographic features of the basement membrane which improved the efficiency of in vitro spermatogenesis in mouse.

The basement membrane is a 3D structure consisting of type IV collagen and laminin, with perlecan and nidogen as cross-linkers between the collagen and laminin fibers (LeBleu et al., 2007). In the seminiferous tubule epithelium, SSC and Sertoli cells are located on the basement membrane thus, SSCs have physical contact with the basement membrane and the supporting Sertoli cells in the niche (de Rooij, 2009). In our study, we provided a 3D surface which mimicked the microenvironment of SSCs, and the positive effects of the PCL/Gel scaffold, as a 3D surface supporting the proliferation and differentiation of SSCs in vitro, were evident.

Although there is no established clinical approach available for fertility preservation in prepubertal boys who are likely to face sterilization upon exposure to chemotherapy and radiotherapy, experimental techniques have been developed which could be beneficial for their fertility preservation (Picton et al.). Due to the rare number of SSCs in testis tissue, culture and expansion are necessary for in vitro differentiation or transplantation. The major problem in cancer patients undergoing fertility restoration by autotransplantation of enriched SSCs or testicular tissue is the risk of reintroducing residual malignant cells via the graft (Picton et al.). This hurdle can be overcome by in vitro spermatogenesis, which also helps to broaden our knowledge about the mechanisms of spermatogenesis. In vitro spermatogenesis can be divided into two stages; cultivation and expansion of SSCs and differentiation into mature sperm. During expansion, it is important to maintain the stemness property of SSCs. In this regard, the involvement of GDNF, LIF and bFGF in self-renewal of SSCs have been discovered in several studies (Meng et al., 2000; Kanatsu-Shinohara et al., 2003). Due to the presence of Sertoli cells and SSCs on the basement membrane of seminiferous tubules, in this study, we employed a nanofiber scaffold made up of PCL polymer blended with Gel to mimic the 3D structure of the basement membrane. PCL is a linear aliphatic polyester, and has been widely used in tissue engineering due to its hydrophobic, semi-crystalline and biocompatible nature. A great deal of attention has been directed toward PCL in the recent years due to these properties (Dash \& Konkimalla; Mondal et al., 2016). One suitable strategy for improving biomaterial-cell interaction is to blend the synthetic biomaterial with ECM proteins such as collagen, fibronectin, laminin etc. In a literature review conducted by Mondal et $a l$., it was found that various studies have utilized PCL nanofiberous scaffold to investigate differentiation into different cell lineages such as cardiomyocyte, neuron, myoblast and etc. (Kim et al., 2010; Chen et al., 2015; Mondal et al.; KarbalaeiMahdi et al., 2017). Although Eslahi et al. demonstrated proliferation of fresh and frozen-thawed mSSCs on PLLA nanofibrous scaffold, there is no study that has demonstrated the differentiation of these cells on such scaffolds. In our study, we demonstrated the proliferation and differentiation of $\mathrm{mSSCs}$ on nanofibrous PCL/Gel scaffold. In Eslahi's study, mSSCs were seeded on PLLA nanofiber scaffold, and he reported that viability and colonization of fresh and frozen-thawed mSSCs on scaffold were improved when compared with control. Shakeri et al. also reported a short-term cultivation of mSSCs on nanofibrillar matrix, and they indicated that a nano-fibrillar matrix had a positive influence on SSCs colonization and implantation into seminiferous epithelium. Similar to these findings, we demonstrated that the number and diameter of colonies of mSSCs seeded on the scaffold were improved during the proliferative cultivation period. The enhanced colony formation observed in our study may be due to the appropriate interaction between the adhered cells and ECMlike scaffold which improved the viability and function of the cells. Woo et al. (2007) reported that mineralization, a major function of osteoblasts, was enhanced when osteoblasts were seeded on nano-fibrous PLLA scaffold compared with a solid-walled 3D scaffold.

In our study, low numbers of Sertoli cells (5\%) were observed after purification, which formed a monolayer of cells after a week of culture (Navid et al.). Due to paracrine secretion and supportive role of Sertoli cells in the survival, proliferation and fate determination of SSCs (Griswold, 1998), we presume that Sertoli cells grown on the nanofibrous scaffold were more functional and created a more appropriate microenvironment for SSCs proliferation and colonization. In agreement with our findings, many studies have reported increased number and diameter of colonies of SSC by improving the quality of culture condition (Baazm et al., 2013; Aliakbari et al., 2017; Navid et al.).

Due to the lack of a unique marker for SSCs identification, a combination of the expression of multiple markers are used to confirm the presence of SSCs. In this study, we analyzed the expression pattern of multiple genes (Plzf, Gfra-1, Itga6 and Id4) which are markers of 
TALEBI, A.; SADIGHI GILANI, M. A.; KORUJI, M.; AI, J.; NAVID, S.; REZAIE, M. J.; JABARI, A.; ASHOURI MOVASSAGH, S.; KHADIVI, F.; SALEHI, M.; HOSHINO, Y. \& ABBASI, M. Proliferation and differentiation of mouse spermatogonial stem cells on a three-dimensional surface composed of PCL/Gel nanofibers. Int. J. Morphol., 37(3):1132-1141, 2019.

spermatogonial stem/progenitor cells in many species (Zheng et al., 2014; He et al., 2015). We observed an increased level of expression of these genes in the cells cultured on PCL scaffold compared with 2D conventional culture system. These observations can be as a result of the increased colonization of SSCs and improved culture condition in the scaffold group. Our results are in agreement with that of Eslahi et al. who reported increased spermatogonia genes expression in fresh mSSCs cultured on PLLA nanofiber. Many other studies have reported that improvement in the cultivation of SSCs in terms of colony number and diameter can result in an increased spermatogonial genes expression (Aliakbari et al.; Navid et al.). In agreement with Eslahi et $a l$. findings, at the end of the proliferative period of culture (First 2 weeks), we observed a significantly higher expression of c-Kit gene (a marker for differentiating spermatogonia) in mSSCs cultured on scaffold. SSC colonies may contain a number of differentiating germ cells during proliferative cultivation, however, c-Kit-expressing spermatogonia represent a modified phenotype of SSCs during culture (Morimoto et al., 2009). Increased expression of undifferentiated spermatogonial cell markers demonstrates that the culture conditions were suitable for mSSCs expansion on the scaffold, and the increased expression of c-Kit gene also shows the positive effects of the scaffold on mSSCs differentiation.

In our study, for the evaluation of the progression of spermatogenesis, we evaluated the expression of the postmeiotic spermatogenic cell markers Scp3, Tp1 and Ptm1 (Meistrich et al., 2003). In agreement with the findings of Minaee Zanganeh et al. (2013) and Fukunaga et al. (2010) who indicated that differentiation and entry into meiosis can be achieved in the absence of LIF, we showed that mSSCs can differentiate toward spermatocyte and spermatid in absence of LIF but in the presence of Sertoli cells. Also, in agreement with our findings, Iwanamo et al. indicated that type-A spermatogonia differentiated toward round spermatid during co-culture with Sertoli cells, and their results were supported by flow cytometric ploidy analysis and expression of Prm-2 gene at the end of 10 days of cultivation (Iwanami et al., 2006).

Lee et al. (2011) fabricated a PLGA microporous scaffold and used it as a 3D surface to demonstrate the in vitro differentiation of spermatocytes from 18-day old rats into spermatid cells. In another study conducted by KarbalaeiMahdi et al., human-induced pluripotent stem cells which differentiated toward neural cells were seeded on PCL/ Gel scaffold, demonstrating that PCL/Gel nanofiber scaffold is capable of supporting differentiation. Our results revealed that spermatogonial cells seeded on scaffold had a higher progression in spermatogenesis which can be associated with the presence of more functional Sertoli cells. Some other studies have also reported that the presence of somatic cells in culture system enhances differentiation stage of spermatogenesis (Stukenborg et al., 2008; Minaee Zanganeh et al.). Finally, in this study, the potential of PCL/Gel scaffold to support SSCs proliferation and in vitro spermatogenesis was demonstrated. The results of this study can be used for research and clinical applications.

In conclusion, our study demonstrated that electrospun PCL/Gel nanofibrous scaffold can support proliferation and colonization of $\mathrm{mSSCs}$ as well as the differentiation of these cells toward haploid spermatid cells. Due to the impact of the surrounding ECM on the behavior of SSCs, nanofiber scaffolds which have morphological similarities to the natural ECM can be used for the propagation and differentiation of SSCs in experimental and clinical applications.

\section{ACKNOWLEDGMENTS}

We are grateful for the funding support provided by the Tehran University of Medical Sciences (Grant No. 34398.). The results described in this article were part of a student thesis.

TALEBI, A.; SADIGHI GILANI, M. A.; KORUJI, M.; AI, J.; NAVID, S.; REZAIE, M. J.; JABARI, A.; ASHOURI MOVASSAGH, S.; KHADIVI, F.; SALEHI, M.; HOSHINO, Y. \& ABBASI, M. Proliferación y diferenciación de células madre espermatogónicas de ratón en una superficie tridimensional compuesta de nanofibras PCL / Gel. Int. J. Morphol., 37(3):11321141, 2019.

RESUMEN: Las células madre espermatogónicas (CME) tienen capacidad de auto renovación y diferenciación esenciales para la producción de esperma a lo largo de la vida reproductiva masculina. El «scaffold» nanofibroso de policaprolactona / gelatina (PCL / Gel) electrohilado imita características importantes de la matriz extracelular (MEC), que puede proporcionar una técnica prometedora para la proliferación y diferenciación de CME in vitro. El objetivo del presente estudio fue investigar los efectos del «scaffold» nanofibroso PCL / Gel en la propagación y diferenciación de CME de ratones neonatos (mSSC). Los mSSC se aislaron enzimáticamente y las células se purificaron mediante un método de siembra diferencial y se sembraron en un «scaffold». Después de 2 semanas, se investigaron la viabilidad, el número y el diámetro de las colonias y la expresión de genes específicos de células espermatogónicas. Después de la propagación de mSSC, las células se cultivaron en un medio de diferenciación en el «scaffold» durante otras 2 semanas, y las células se analizaron mediante PCR en tiempo real. El número de colonias $\operatorname{mSSC}(\mathrm{P}<0,01)$ y los nive- 
les de expresión de los genes espermatogónicos específicos Plzf e Inga6 ( $\mathrm{P}<0,01)$ y también los genes de diferenciación c-Kit, Tp1 y Ptm1 $(\mathrm{P}<0,05)$ fueron mayores en el grupo de «scaffold» en comparación con el control durante el período de cultivo. Concluimos que los mSSC pueden expandirse y diferenciarse en células espermátidas en un «scaffold» de nanofibras PCL / Gel con parámetros de desarrollo mejorados.

PALABRAS CLAVE: Célula madre adulta de la línea germinal; Infertilidad masculina; Diferenciación celular; Policaprolactona; nanofibras.

\section{REFERENCES}

Aliakbari, F.; Sedighi Gilani, M. A.; Yazdekhasti, H.; Koruji, M.; Asgari, H. R.; Baazm, M.; Izadyar, F.; Kharrazi Nejad, E.; Khanezad, M. \& Abbasi, M. Effects of antioxidants, catalase and a-tocopherol on cell viability and oxidative stress variables in frozen-thawed mice spermatogonial stem cells. Artif. Cells Nanomed. Biotechnol., 45(1):638, 2017.

Baazm, M.; Abolhassani, F.; Abbasi, M.; Habibi Roudkenar, M.; Amidi, F. $\&$ Beyer, C. An improved protocol for isolation and culturing of mouse spermatogonial stem cells. Cell. Reprogram., 15(4):329-36, 2013.

Boitani, C.; Di Persio, S.; Esposito, V. \& Vicini, E. Spermatogonial cells: mouse, monkey and man comparison. Semin. Cell Dev. Biol., 59:7988, 2016.

Chen, Y.; Zeng, D.; Ding, L.; Li, X. L.; Liu, X. T.; Li, W. J.; Wei, T.; Yan, S.; Xie, J. H.; Wei, L.; et al. Three-dimensional poly-(e-caprolactone) nanofibrous scaffolds directly promote the cardiomyocyte differentiation of murine-induced pluripotent stem cells through Wnt/ b-catenin signaling. B. M. C. Cell Biol., 16:22, 2015.

Dash, T. K. \& Konkimalla, V. B. Polycaprolactone based formulations for drug delivery and tissue engineering: A review. J. Control. Release, 158(1):15-33, 2012

de Rooij, D. G. The spermatogonial stem cell niche. Microsc. Res. Tech., 72(8):580-5, 2009.

Dohle, G. R. Male infertility in cancer patients: Review of the literature. Int. J. Urol., 17(4):327-31, 2010.

Eslahi, N.; Hadjighassem, M. R.; Joghataei, M. T.; Mirzapour, T.; Bakhtiyari, M.; Shakeri, M.; Pirhajati, V.; Shirinbayan, P. \& Koruji, M. The effects of poly L-lactic acid nanofiber scaffold on mouse spermatogonial stem cell culture. Int. J. Nanomedicine, 8:4563-76, 2013.

Farzamfar, S.; Naseri-Nosar, M.; Samadian, H.; Mahakizadeh, S.; Tajerian, R.; Rahmati, M.; Vaez, A. \& Salehi, M. Taurine-loaded poly (ecaprolactone)/gelatin electrospun mat as a potential wound dressing material: In vitro and in vivo evaluation. J. Bioact. Compat. Polym., 33(3):282-94, 2017.

Fukunaga, N.; Teramura, T.; Onodera, Y.; Takehara, T.; Fukuda, K. \& Hosoi, Y. Leukemia inhibitory factor (LIF) enhances germ cell differentiation from primate embryonic stem cells. Cell. Reprogram., 12(4):369-76, 2010.

Goossens, E.; Van Saen, D. \& Tournaye, H. Spermatogonial stem cell preservation and transplantation: from research to clinic. Hum. Reprod., 28(4):897-907, 2013.

Griswold, M. D. Spermatogenesis: the commitment to meiosis. Physiol. Rev., 96(1):1-17, 2016.

Griswold, M. D. The central role of Sertoli cells in spermatogenesis. Semin. Cell Dev. Biol., 9(4):411-6, 1998.

Hai, Y.; Hou, J.; Liu, Y.; Liu, Y.; Yang, H.; Li, Z. \& He, Z. The roles and regulation of Sertoli cells in fate determinations of spermatogonial stem cells and spermatogenesis. Semin. Cell Dev. Biol., 29:66-75, 2014.
He, Y.; Chen, X.; Zhu, H. \& Wang, D. Developments in techniques for the isolation, enrichment, main culture conditions and identification of spermatogonial stem cells. Cytotechnology, 67(6):921-30, 2015.

Huleihel, M.; Nourashrafeddin, S. \& Plant, T. M. Application of threedimensional culture systems to study mammalian spermatogenesis, with an emphasis on the rhesus monkey (Macaca mulatta). Asian J. Androl., 17(6):972-80, 2015.

Ibtisham, F.; Wu, J.; Xiao, M.; An, L.; Banker, Z.; Nawab, A.; Zhao, Y. \& $\mathrm{Li}, \mathrm{G}$. Progress and future prospect of in vitro spermatogenesis. Oncotarget, 8(39):66709-27, 2017.

Iwanami, Y.; Kobayashi, T.; Kato, M.; Hirabayashi, M. \& Hochi, S. Characteristics of rat round spermatids differentiated from spermatogonial cells during co-culture with Sertoli cells, assessed by flow cytometry, microinsemination and RT-PCR. Theriogenology, 65(2):288-98, 2006

Jalayeri, M.; Pirnia, A.; Najafabad, E. P.; Varzi, A. M. \& Gholami, M. Evaluation of alginate hydrogel cytotoxicity on three-dimensional culture of type A spermatogonial stem cells. Int. J. Biol. Macromol., 95:888-94, 2017.

Jan, S. Z.; Hamer, G.; Repping, S.; de Rooij, D. G.; van Pelt, A. M. \& Vormer, T. L. Molecular control of rodent spermatogenesis. Biochim. Biophys. Acta, 1822(12):1838-50, 2012.

Kanatsu-Shinohara, M.; Ogonuki, N.; Inoue, K.; Miki, H.; Ogura, A.; Toyokuni, S. \& Shinohara, T. Long-term proliferation in culture and germline transmission of mouse male germline stem cells. Biol. Reprod., 69(2):612-6, 2003.

KarbalaeiMahdi, A.; Shahrousvand, M.; Javadi, H. R.; Ghollasi, M.; Norouz, F.; Kamali, M. \& Salimi, A. Neural differentiation of human induced pluripotent stem cells on polycaprolactone/gelatin bi-electrospun nanofibers. Mater. Sci. Eng. C Mater. Biol. Appl., 78:1195-202, 2017.

Kim, M. S.; Jun, I.; Shin, Y. M.; Jang, W.; Kim, S. I. \& Shin, H. The development of genipin-crosslinked poly(caprolactone) (PCL)/gelatin nanofibers for tissue engineering applications. Macromol. Biosci., 10(1):91-100, 2010.

LeBleu, V. S.; MacDonald, B. \& Kalluri, R. Structure and function of basement membranes. Exp. Biol. Med. (Maywood), 232(9):1121-9, 2007.

Lee, J. H.; Kim, H. J.; Kim, H.; Lee, S. J. \& Gye, M. C. In vitro spermatogenesis by three-dimensional culture of rat testicular cells in collagen gel matrix. Biomaterials, 27(14):2845-53, 2006.

Lee, J. H.; Oh, J. H.; Lee, J. H.; Kim, M. R. \& Min, C. K. Evaluation of in vitro spermatogenesis using poly(D,L-lactic-co-glycolic acid) (PLGA)based macroporous biodegradable scaffolds. J. Tissue Eng. Regen. Med., 5(2):130-7, 2011.

Ma, Z.; Kotaki, M.; Inai, R. \& Ramakrishna, S. Potential of nanofiber matrix as tissue-engineering scaffolds. Tissue Eng., 11(1-2):101-9, 2005.

Mei, X. X.; Wang, J. \& Wu, J. Extrinsic and intrinsic factors controlling spermatogonial stem cell self-renewal and differentiation. Asian J. Androl., 17(3):347-54, 2015.

Meistrich, M. L.; Mohapatra, B.; Shirley, C. R. \& Zhao, M. Roles of transition nuclear proteins in spermiogenesis. Chromosoma, 111(8):4838, 2003.

Meng, X.; Lindahl, M.; Hyvönen, M. E.; Parvinen, M.; de Rooij, D. G.; Hess, M. W.; Raatikainen-Ahokas, A.; Sainio, K.; Rauvala, H.; Lakso, M.; et al. Regulation of cell fate decision of undifferentiated spermatogonia by GDNF. Science, 287(5457):1489-93, 2000.

Minaee Zanganeh, B.; Rastegar, T.; Habibi Roudkenar, M.; Ragerdi Kashani, I.; Amidi, F.; Abolhasani, F. \& Barbarestani, M. Co-culture of spermatogonial stem cells with sertoli cells in the presence of testosterone and FSH improved differentiation via up-regulation of post meiotic genes. Acta Med. Iran, 51(1):1-11, 2013.

Mondal, D.; Griffith, M. \& Venkatraman, S. S. Polycaprolactone-based biomaterials for tissue engineering and drug delivery: Current scenario and challenges. Int. J. Polymer. Mater., 65(5):255-65, 2016.

Morimoto, H.; Kanatsu-Shinohara, M.; Takashima, S.; Chuma, S.; Nakatsuji, N.; Takehashi, M. \& Shinohara, T. Phenotypic plasticity of mouse spermatogonial stem cells. PLoS One, 4(11):e7909, 2009. 
TALEBI, A.; SADIGHI GILANI, M. A.; KORUJI, M.; AI, J.; NAVID, S.; REZAIE, M. J.; JABARI, A.; ASHOURI MOVASSAGH, S.; KHADIVI, F.; SALEHI, M.; HOSHINO, Y. \& ABBASI, M. Proliferation and differentiation of mouse spermatogonial stem cells on a three-dimensional surface composed of PCL/Gel nanofibers. Int. J. Morphol., $37(3): 1132-1141$, 2019.

Navid, S.; Abbasi, M. \& Hoshino, Y. The effects of melatonin on colonization of neonate spermatogonial mouse stem cells in a threedimensional soft agar culture system. Stem Cell. Res. Ther, 8(1):233, 2017.

O'Brien, F. J. Biomaterials \& scaffolds for tissue engineering. Mater. Today, 14(3):88-95, 2011

Onofre, J.; Baert, Y.; Faes, K. \& Goossens, E. Cryopreservation of testicular tissue or testicular cell suspensions: a pivotal step in fertility preservation. Hum. Reprod. Update, 22(6):744-61, 2016.

Picton, H. M.; Wyns, C.; Anderson, R. A.; Goossens, E.; Jahnukainen, K.; Kliesch, S.; Mitchell, R. T.; Pennings, G.; Rives, N.; Tournaye, H.; et al. A European perspective on testicular tissue cryopreservation for fertility preservation in prepubertal and adolescent boys. Hum. Reprod., 30(11):2463-75, 2015.

Sabir, M. I.; Xu, X. \& Li, L. A review on biodegradable polymeric materials for bone tissue engineering applications. J. Mater. Sci., 44(21):571324, 2009.

Salehi, M.; Naseri-Nosar, M.; Ebrahimi-Barough, S.; Nourani, M.; Khojasteh, A.; Hamidieh, A. A.; Amani, A.; Farzamfar, S. \& Ai, J. Sciatic nerve regeneration by transplantation of Schwann cells via erythropoietin controlled-releasing polylactic acid/multiwalled carbon nanotubes/gelatin nanofibrils neural guidance conduit. J. Biomed. Mater. Res. B Appl. Biomater, 106(4):1463-76, 2018.

Shakeri, M.; Kohram, H.; Shahverdi, A.; Shahneh, A. Z.; Tavakolifar, F.; Pirouz, M.; Shahrebabak, H. M.; Koruji, M. \& Baharvand, H. Behavior of mouse spermatogonial stem-like cells on an electrospun nanofibrillar matrix. J. Assist. Reprod. Genet., 30(3):325-32, 2013.

Shams, A.; Eslahi, N.; Movahedin, M.; Izadyar, F.; Asgari, H. \& Koruji, M. Future of spermatogonial stem cell culture: application of nanofiber scaffolds. Curr. Stem Cell Res. Ther, 12(7):544-53, 2017.

Stukenborg, J. B.; Wistuba, J.; Luetjens, C. M.; Elhija, M. A.; Huleihel, M.; Lunenfeld, E.; Gromoll, J.; Nieschlag, E. \& Schlatt, S. Coculture of spermatogonia with somatic cells in a novel three-dimensional softagar-culture-system. J. Androl., 29(3):312-29, 2008.

Woo, K. M.; Jun, J. H.; Chen, V. J.; Seo, J.; Baek, J. H.; Ryoo, H. M.; Kim, G. S.; Somerman, M. J. \& Ma, P. X. Nano-fibrous scaffolding promotes osteoblast differentiation and biomineralization. Biomaterials, 28(2):335-43, 2007.

Yoshida, S. From cyst to tubule: innovations in vertebrate spermatogenesis. Wiley Interdiscip. Rev. Dev. Biol., 5(1):119-31, 2016.

Zheng, Y.; Zhang, Y.; Qu, R.; He, Y.; Tian, X. \& Zeng, W. Spermatogonial stem cells from domestic animals: progress and prospects. Reproduction, 147(3):R65-74, 2014.

\author{
Corresponding author: \\ Mehdi Abbasi, PhD, \\ Department of Anatomy \\ School of Medicine \\ Tehran University of Medical Sciences \\ Tehran \\ IRAN
}

E-mail: abbasima@tums.ac.ir

Received: 07-12-2018

Accepted: 08-04-2019 